\title{
The Open Textbook Toolkit: Seeding Successful Partnerships for Collaboration between Academic Libraries and University Presses
}

MIRA WALLER, WILLIAM M. CROSS, and

\section{LILLIAN RIGLING}

Libraries and university presses coexist in a complex and increasingly consolidated scholarly communication ecosystem. Each brings different strengths, values, and viewpoints that can inform and enrich a joint project. In this paper we discuss potential barriers to and benefits of collaboration between academic libraries and university presses and introduce a case study of such a collaboration: the Open Textbook Toolkit. This project, funded by a grant from the Institute of Museum and Library Services, is currently investigating the components needed to support faculty in one discipline, psychology, who are considering adopting open educational resources. By leveraging both library and press expertise, the Toolkit represents one model for fruitful collaboration.

Keywords: open access, library-press collaboration, open educational resource, academic infrastructure

\section{INTRODUCTION}

Libraries and university presses coexist in a complex and increasingly consolidated scholarly communication ecosystem. That consolidation has accelerated over recent years, leading to the loss of independence for many small and non-profit publishing operations and societies, and squeezing others out of existence. Academic and research libraries have also felt the sting of this consolidation as it contributes to an unbalanced state in the current scholarly communication ecosystem and exacerbates the content pricing and purchasing issues often referred to as the 'journal pricing crisis.' On the face of it, academic libraries and university presses would seem to be natural partners and collaborators. Each ultimately 
serves academia and scholarship, and both report in some way to a university or college system. Even their financial situations are similar in some ways, with most libraries facing stagnant or shrinking collections budgets and many university presses facing lower revenues and increased poaching from commercial publishers.

There is a strong case to be made for the value of scholarly output built on a partnership between academic libraries and university presses. Each brings different strengths, values, and viewpoints that can inform and enrich a joint project. In addition, libraries have a direct relationship with faculty, researchers, and students that can provide insights into their needs and behaviours related to scholarly communication. The reputation of a university press can add weight and credibility to scholarly output in a way that directly publishing on the Web, at least currently, cannot.

In some places this collaboration has begun to develop, but these collaborations are often unbalanced or incomplete. Libraries are increasingly providing some form of publishing service, ${ }^{1}$ such as the work done at the University of Michigan Library, which has formed publishing units, and at Duke University Libraries, which is running instantiations of Open Journal Systems to support publishing by faculty. Increasingly university presses are reporting to the library, a merger that began as an administrative cost-saving measure but that has the promise of developing into a true collaboration capable of strengthening the scholarly communication ecosystem. ${ }^{2}$ As these reporting structures continue to mature, we may see an organic move toward a model of scholarly publishing that combines the best of what libraries and presses offer. Successful restructuring may also bring deeper understanding between libraries and presses that do not share this reporting structure and may reinforce the value of leveraging each other's strengths.

Many presses and libraries are frustrated in the current ecosystem, but for a number of reasons, it can be difficult to find viable projects that elicit the same enthusiasm from both parties. Partnership can be difficult when the partners come from different areas, when they are meant to be truly equal, and when the output of their work is ongoing. However, it is often these types of collaborations, when successful, that can be the most rewarding and beneficial. In this paper we discuss some barriers to and benefits of collaboration between academic libraries and university presses, explore open educational resources (OERs) as a promising area for collaboration, and review our work to date on the Open Textbook Toolkit as a case study of press-library collaboration. 


\section{POTENTIAL BARRIERS TO COLLABORATION}

Academic libraries and university presses share a similar ethos and a common mission with overlapping areas of emphasis in the creation and dissemination of scholarly content. As part of the scholarly communication ecosystem, libraries and presses serve as a philosophical and practical counterweight to commercial entities. Both are mission driven and have a stake in what happens to and in the scholarly communication ecosystem. As one recent report from the Association of American University Presses notes, 'presses and libraries want the same thing ... widespread, cost-effective distribution of scholarly products. They have shared problems and a shared future. ${ }^{3}$

Despite these shared aims, there are also crucial differences between libraries and presses that can be barriers to successful collaboration. One significant difference between academic libraries and university presses is how they are evaluated. For university presses, markers of success primarily come from outside the university. Presses strive to acquire authors with groundbreaking work from outside their institution, and when faced with the prospect of publishing works from their own institution's faculty, the specter of being seen as a vanity press may loom large. Academic libraries, while also concerned with external recognition and approval, primarily receive their validation from within their university. Academic libraries are evaluated for their ability to collaborate and provide services to their university's faculty, researchers, and students, with the wider world seen as important but secondary. ${ }^{4}$

Another important distinction between libraries and presses is their respective business models. While academic libraries are funded by an operating budget provided by the university, university press budgets usually come from revenues generated by the press plus a subvention from the university. ${ }^{5}$ The size of subvention varies widely and has an effect on how a press operates. University presses face the challenge of running a cost-recovery operation as a mission-based business, while academic libraries face the challenge of running an operation on a budget ultimately controlled by administrators - and often by state governments - outside the library.

Finally, while academic libraries and university presses each have important expertise, it is not always clear that they appreciate or even recognize each other's strengths. Over the past several decades, factors related to the economy, journal prices, technology, and changes in 
scholar behaviour have led to increasing tensions between libraries and presses. ${ }^{6}$ At times it seems that they may have differing ideas about the important and necessary components of scholarly publishing. To have a successful partnership, each collaborator must bring something to the table that the other recognizes and values. There must be a common vocabulary and a shared understanding of values, at least for the project or product at hand.

\section{BENEFITS OF COLLABORATION}

Scholars like Roh have documented 'both the acrimonious and collaborative relationships between university presses and academic libraries, ${ }^{7}$ and partnerships have developed at a variety of institutions ${ }^{8}$ dating back at least to Day's seminal 1995 article, 'The Need for Library and University Press Collaboration.' ${ }^{9}$ While the differences between libraries and presses can be potential barriers to collaboration, their diversity in thought, approaches, and business models can also lead to innovation by pushing both parties outside their comfort zones. University presses and libraries can help each other tip the scholarly communication ecosystem back into balance by figuring out how and when it makes sense to work together. ${ }^{10}$ Joint projects that take advantage of their complementary areas of expertise and shared priorities can increase efficiencies and lower costs for both. ${ }^{11}$

Library-press partnerships succeed in areas such as alternative, experimental models of scholarly communication, especially preprint operations and open access. For example, the University of Michigan Library, through Michigan Publishing, is engaging in 'publishing as pedagogy' where the 'act of publishing is a means to an end rather than an end it itself.' Two initiatives at Michigan are the Michigan Journal of Medicine and the Café Shapiro Anthology. ${ }^{12}$ We believe that a key to successful collaboration between presses and libraries may be to find the right projects and initiatives to collaborate on - to find the sweet spot, so to speak.

OPEN TEXTBOOKS AS A PROMISING AREA FOR PARTNERSHIP

Despite the challenges described above, presses and libraries have a clear 'shared stake in scholarly communication' ${ }^{13}$ that has been explored in the context of open access, a context in which libraries and presses have found partnership to be 'a win-win arrangement'14 that demonstrates common alignment and achieves university goals. 
Our experiences suggest that OERs present a similarly ripe opportunity for collaboration. ${ }^{15}$ As scholars such as Peek have written, stakeholders ' responded to the journal crisis in a number of ways with some becoming involved with the open access movement. It is with this same concern with affordability and access to knowledge that librarians have become involved with [open education] initiatives. ${ }^{16}$ Both presses and libraries are deeply committed to engaging with open culture in a variety of contexts, and they have each identified open education as a promising avenue to explore. ${ }^{17}$

In many ways open education presents an even more compelling case for partnership than open access journals or monographs. At roughly $\$ 14$ billion, the textbook market is a third again as large as the market for journals. The escalating price of textbooks has led some to conclude that the current textbook market is broken and that intervention is badly needed. ${ }^{18}$ With their shared academic values, libraries and presses have an opportunity to intervene and reclaim textbooks from the for-profit publishers that have captured the textbook market. The textbook market, which has a new class of motivated buyers every semester, is also rapidly changing, with students actively exploring alternatives in used and grey textbook markets and instructional technologies regularly coming into and falling out of favour. ${ }^{19}$ The market also has clearly defined gaps to fill in the form of recurring courses for which no textbook currently exists. ${ }^{20}$ In this rapidly changing market, libraries and presses are uniquely positioned to develop services and materials that leverage their specific expertise by grounding their work in the needs of a specific department, campus, or community. ${ }^{21}$

This unique opportunity to connect to a specific academic community has been the hallmark of early press-library partnerships in this area. System-wide efforts like Affordable Learning Georgia have grounded their work in a specific community and have been deliberate about building services around the library and press that meet the needs of that community. ${ }^{22}$ Similarly, library-press partnerships like that at Oregon State University have led to a new emphasis on creating open textbooks, ${ }^{23}$ and libraries and presses have collaborated with individual departments to create open textbooks for particular courses. ${ }^{24}$ These library-press partnerships catering to a particular community provide clear goals, a known audience, and demonstrable value for everyone involved. Through collaboration between our own library and university 
press, we are developing a promising new OER initiative: the Open Textbook Toolkit.

\section{DEVELOPING THE OPEN TEXTBOOK TOOLKIT}

The University of North Carolina (UNC) system provides an excellent test bed for this type of collaboration. As members of the UNC system, North Carolina State University (NCSU) and UNC Press have a clear relationship on paper, but we have often struggled to leverage this relationship in practice. There are many reasons for this disconnect. For example, UNC Press describes itself as 'an affiliate of the 16-campus UNC system and its purpose remains to advance scholarship and to serve the people of the state and the region. ${ }^{25}$ Historically, however, the work of UNC Press has been grounded in collaboration with a single institution: the University of North Carolina at Chapel Hill. In addition, NCSU's academic strengths lie in STEM (science, technology, engineering, and math) fields, while UNC Press tends to publish more in the humanities and social sciences.

Like other libraries and presses around the nation, both NCSU Libraries and UNC Press have been interested in exploring new areas of library-press collaboration. In fact, UNC Press received a grant in 2015 from the Andrew W. Mellon Foundation to explore potential collaborators for digital publishing. ${ }^{26}$ NCSU Libraries have also been investigating partnership opportunities, and our work on open education presented an excellent opportunity.

\section{The Alt-Textbook Project at NCSU}

Recognizing the financial pressures facing our students and the opportunity to address them by collaborating with faculty to seed innovation, NCSU Libraries began developing our Alt-Textbook project in 2013. ${ }^{27}$ Inspired by similar programs at Temple University Libraries and University of Massachusetts at Amherst Libraries, NCSU's Alt-Textbook project provides small grants of between $\$ 500$ and \$2000 to individual instructors who are willing to replace an existing commercial textbook with an OER.

The Alt-Textbook project has successfully converted twenty courses to open or free educational resources, easing the financial burden of buying textbooks for our students by over $\$ 300,000$. This project has not only attracted faculty looking to reduce the cost of their learning 
materials but also faculty who are eager to create or use innovative resources that do things a traditional textbook cannot. These resources have included both traditionally formatted open textbooks as well as student-made videos, $3 \mathrm{D}$ scan files and renderings, remixed popular articles, interactive tutorials, and iterative courses developed through versioning tools like GitHub.

Although NCSU Libraries' Copyright and Digital Scholarship Center manages the Alt-Textbook project, it is a collaborative effort across library departments. This project is designed to be collaborative by bringing together librarians and staff with expertise in open culture, instruction and pedagogy, Web applications and hosting, collections, and access services, as well as librarians with subject expertise-all to provide comprehensive and holistic support to faculty interested in adopting OERs.

Our experience running the Alt-Textbook project has demonstrated a number of barriers to adopting or creating OERs. Though we have had great success with the project, we are also becoming increasingly aware that many faculty struggle with discovering applicable OERs, evaluating quality, and developing professional, polished resources. Our faculty are not unusual in this respect. Studies have shown that students perform as well or better in courses using OERs, ${ }^{28}$ but instructors at American universities have been hesitant to replace their course materials with OERs. The Babson report, in a survey of over 3000 faculty members, found that only 5.3 per cent of courses were using an openly licensed resource as a required textbook. ${ }^{29}$ Faculty members cited the biggest barrier to using OERs in their courses as the limited availability of such resources. Faculty members who had previous awareness of OERs also expressed concern about the quality of materials. Instructors need new resources that are customizable, trusted, and high in quality.

While NCSU Libraries have much to offer faculty with questions about copyright, metadata, and course design, instructors also face a set of issues where press expertise would be valuable. To combine our expertise and develop a collaborative partnership, we began to investigate opportunities to work together on these issues.

\section{Conception of the Open Textbook Toolkit}

Without systematic support and an underlying infrastructure for easily creating a robust and trusted OER, it is difficult to imagine that many 
educators will want to invest their time and effort in creating or adopting these types of resources. To bridge this gap in expertise, we decided to develop a set of tools, a 'Toolkit,' that breaks down the creation of an open textbook or similar type of OER into simple, flexible, and scalable components. Our hope is to enable educators to create these resources more easily. The Toolkit will bring together both library and press expertise, but it also requires a deep understanding of instructors' discipline-specific needs. Our first step was to investigate the specific needs of faculty who are considering OERs. Resources such as the Babson report have identified high-level questions, but we recognize that each discipline is unique in its practices and norms around teaching, learning, research, and information sharing, and OERs must be grounded in this context.

For our initial research and development, we decided to focus on the discipline of psychology. Psychology has consistently been one of the most popular undergraduate majors at institutions of higher learning. Approximately 117,000 undergraduate degrees were conferred with a psychology major in $2013-14,{ }^{30}$ and this number has been consistently rising since the 1970s. Understanding the tools and support that psychology experts need to create and adopt OERs increases the potential of these resources to have a broad impact on undergraduate education and student success.

In order to investigate the needs of psychology instructors around OERs, NCSU Libraries developed a proposal for a planning grant from the Institute of Museum and Library Services. This funding agency has made open education a priority and has a history of supporting the development of new digital platforms such as the Toolkit. UNC Press is obviously a close partner and it supported the grant with discussions about partnership opportunities as well as a formal letter of support. The Open Textbook Network (OTN), an alliance of higher education institutions committed to access, affordability, and student academic success through the use of open textbooks, also offered both intellectual guidance and a formal letter of support. Partnership with UNC Press and the OTN helped ground our work in terms of addressing both the quality and discoverability of OERs, the primary barriers identified in the Babson report. ${ }^{31}$ The Student Public Interest Research Groups (Student PIRGs) also offered a letter of support, and we identified a 
second set of stakeholders, including the American Psychological Association and the cutting-edge psychology preprint service PsyArXiv, as important parties that would need to be involved as research moved forward.

The grant was awarded in April 2017, and our research is proceeding in three phases: 1) a planning and preparation phase; 2) a survey and focus group phase; and 3) an evaluation, reporting, and dissemination phase. Planning and preparation have involved deep research, consultation with our primary partners, initial discussion with other identified partners, and the design of a national survey targeting psychology instructors and students. The survey, slated to launch at the beginning of the fall semester, will investigate the practices and needs of instructors who may be interested in adopting or creating an OER and the needs of their students. It will also help to identify gaps in support for these experts that make it difficult for them to create robust, tailored materials.

The survey results will also be used to develop and run a series of focus groups across North America at psychology conferences and gatherings to develop a deeper understanding of these issues. We will release the properly anonymized findings and instruments of the survey and focus groups as openly licensed resources so that other stakeholders can review our research. We hope that others will use these resources to do similar research on other academic communities. Finally, we will develop a white paper that identifies the optimal components of the subject-specific, simple, flexible, and scalable Toolkit for the creation and adoption of OERs for psychology, as well as establish what kinds of support are necessary for subject experts to create these resources. The report will include actionable recommendations for stakeholders across psychology and set the stage for NCSU Libraries and UNC Press to develop the Toolkit.

\section{Next Steps: Forging a Lasting Library-Press Partnership}

Academic libraries and university presses possess distinct areas of expertise that will inform the Toolkit. For example, academic libraries possess knowledge and expertise in areas such as metadata, preservation, and scholarly content. University presses have experience and expertise in areas such as peer review, marketing, and editorial management. In combination, NCSU Libraries and UNC Press possess the skills and knowledge to cover most, if not all, the areas needed to create the 
subject-specific, simple, flexible, and scalable Toolkit for the creation and adoption of OERs. This will be further strengthened by the findings from our planning grant research into the practices and needs of psychology instructors and students for tailored educational resources. Although both parties possess expertise in the scholarly communication ecosystem, neither is an expert in scholarly communication as it relates to psychology, which creates common ground and an opportunity for growth. This gives both NCSU Libraries and UNC Press an area in which they can innovate together, while exercising their different areas of expertise.

Though we are in the early stages of this partnership, working together has already revealed new intersections for NCSU Libraries and UNC Press to explore. Through our budding relationship with UNC Press, centred on the digital publication of OERs, we have had the opportunity to discuss other mutual interests in open access publishing, and it has expanded both our professional circle and skill set. As we move forward with this project, designing and implementing the Toolkit will give us a chance to develop new working relationships and a deeper appreciation for what each partner brings to the table. Creating the Toolkit will also leverage our complementary skills in the service of a shared mission to develop a product that is highly valued by our university system. More than the substance of the resource, the process of creating the Toolkit represents a blueprint for collaboration that can be extended to new projects in the years to come.

\section{CONCLUSION}

As Sutton and Chadwell noted in a 2014 article on library-press collaboration, 'open textbook publishing reinforces the compelling argument that academia needs to assume greater ownership of the distribution of the content it creates. Instead of giving that content away to external publishers so it can be sold back to students at often egregious prices, higher education could invest in systems that take advantage of library and press expertise surrounding the creation and dissemination of information in various formats. ${ }^{32}$ Libraries, university presses, and funding agencies such as the Institute of Museum and Library Services have all identified open textbooks as an opportunity for transforming scholarly communication. The Open Textbook Toolkit represents an exciting opportunity to do exactly this. By bringing together library and press 
partners on a clear, mission-driven project, the Toolkit addresses a specific problem in scholarly communication, but it also lays the foundation for deep, ongoing collaboration by partners who have more in common than many might imagine.

mira WAller is the Interim Department Head of Research Engagement in the North Carolina State University Libraries. She leads an engagement-centered team that supports research productivity and flexible modes of learning through access to expert assistance, research-enhancing technologies and spaces, and innovative services across the lifecycle of research, scholarship, and pedagogy. Waller was previously Director of Publishing Services for Project Euclid.

william m. Cross is the Director of the Copyright and Digital Scholarship Center in the North Carolina State University Libraries. He speaks and writes nationally on copyright, scholarly communication, and open culture.

LILLIAN RIGLING is a Research and Instructional Services Librarian at Western Libraries. She provides research, collections, and instruction support across the social sciences. She also leads campus-wide efforts on open education support. Previously, Lillian was a librarian at North Carolina State University Libraries, where she was appointed in the Copyright and Digital Scholarship Center and the User Experience Department.

\section{NOTES}

1. Patrick Alexander et al. of the AAUP Library Relations Committee, Library-Press Collaboration Survey (Washington, D.C.: Association of American University Presses, 2013), http://www.aaupnet.org/images/stories/data/librarypresscollaboration_report_ corrected.pdf.

2. Charles Watkinson, 'Why Marriage Matters: A North American Perspective on Press/Library Partnerships,' Learned Publishing 29 (2016): 342-7, doi:10.1002/ leap.1044.

3. Mary Rose Muccie, Joe Lucia, Elliot Shore, Clifford Lynch, and Peter Berkery, Across the Great Divide: Findings and Possibilities for Action from the 2016 Summit Meeting of Academic Libraries and University Presses with Administrative Relationships (Washington, D.C.: Association of American University Presses, 2013), http://www.aaupnet.org/resources/for-members/data-collection-and-analysis/ library-press-collaboration-survey.

4. Muccie et al., Across the Great Divide.

5. Alexander et al., Library-Press Collaboration Survey. 
6. Charlotte Roh, 'Library-Press Collaborations: A Study Taken on Behalf of the University of Arizona,' Journal of Librarianship and Scholarly Communication 2, no. 4 (2014), doi:10.7710/2162-3309.1102.

7. Roh, 'Library-Press Collaborations.'

8. Nancy. L. Eaton, Bonnie MacEwan, and Peter J. Potter, 'Learning to Work Together: The Libraries and the University Press at Penn State,' Journal of Scholarly Publishing 35, no. 4 (2004): 215-20, doi:10.3138/jsp.35.4.215.

9. Colin Day, 'The Need for Library and University Press Collaboration,' Collection Management 19, nos. 3-4 (1995): 107-15, doi:10.1300/J105v19no3_10.

10. Catherine A. Mitchell and Laura Cerruti, 'Local, Sustainable, and Organic Publishing: A Library-Press Collaboration at the University of California,' Against the Grain 20, no. 6 (2008): 22-6.

11. Roh, 'Library-Press Collaborations.'

12. Laurie Alexander, Jason Colman, Meredith Kahn, Amanda Peters, Charles Watkinson, and Rebecca Welzenbach, 'Publishing as Pedagogy: Connecting Library Services and Technology,' EDUCASE Review, January 11, 2016, http:// er.educause.edu/articles/2016/1/publishing-as-pedagogy-connecting-libraryservices-and-technology.

13. Eaton, MacEwan, and Potter, 'Learning to Work Together.'

14. Tony Horava, 'Making OA Monographs Happen: Library-Press Collaboration at the University of Ottawa, Canada,' Insights 29, no. 1 (2016): 57-63, doi:10.1629/ uksg.278.

15. Nancy L. Maron, 'Opening the Textbook Market: New Opportunities for Libraries and Publishers?', Ithaka $S+R$, 2014, http://www.sr.ithaka.org/wp-content/mig/files/ SR_BriefingPaper_Textbook_20140306.pdf.

16. Robin Peek, 'Textbooks in Turmoil,' Information Today 29, no. 5 (2012): 26.

17. William M. Cross, 'Library Expertise Driving Pedagogical Innovation: Bringing "Open” to the Classroom with Open Educational Resources,' in Leading the 21st-Century Academic Library, ed. Kevin L. Smith and Katherine A. Dickson (Lanham, MD: Rowman and Littlefield, 2016), 71-96; Corinne Ruff, 'UNC Press to Offer Publishing Services for Professors' DIY Textbooks,' Chronicle of Higher Education, May 31, 2016, http://www.chronicle.com/article/UNC-Press-to-OfferPublishing/236646.

18. U.S. PIRG Education Fund and the Student PIRGs, Fixing the Broken Textbook Market (Washington, D.C.: Student PIRGs, 2014), http://www.uspirg.org/reports/ usp/fixing-broken-textbook-market.

19. Larry Katz, Megan C. Hallam, Michael M. Duvall, and Zoe Polsky, 'Considerations for Using Personal Wi-Fi Enabled Devices as "Clickers" in a Large University Class,' Active Learning in Higher Education 18, no. 1 (2017), doi:10.1177/ 1469787417693495. 
20. Alex Carroll, 'When the Textbook You Need Hasn't Been Written Yet,' NCSU Libraries, January 19, 2017, https://www.lib.ncsu.edu/stories/when-the-textbookyou-need-hasn\%E2\%80\%99t-been-written-yet.

21. Kristine Alpi, William Cross, Gregory Raschke, and Madison Sullivan, 'The NCSU Libraries' Alt-Textbook Project: Open Education That Opens a Door to the Library,' in Textbooks in Academic Libraries, ed. C. Diaz (Chicago: ALCTS, forthcoming).

22. Jeff Gallant, 'Librarians Transforming Textbooks: The Past, Present, and Future of the Affordable Learning Georgia Initiative,' Georgia Library Quarterly 52, no. 2 (2015), http://digitalcommons.kennesaw.edu/glq/vol52/iss2/8.

23. Shan C. Sutton and Faye A. Chadwell, 'Open Textbooks at Oregon State University: A Case Study of New Opportunities for Academic Libraries and University Presses,' Journal of Librarianship and Scholarly Communication 2, no. 4 (2014), doi:10.7710/2162-3309.1174.

24. See, for example, Greg Raschke and Shelby Shanks, 'Water on a Hot Skillet: Textbooks, Open Educational Resources, and the Role of the Library,' in The No Shelf Required Guide to E-Book Purchasing: A Library Technology Report, ed. S. Polanka (Chicago: ALA Editions, 2011), 52-7.

25. UNC Press, 'History of UNC Press,' https://www.uncpress.org/about/.

26. Jane Stancill, 'UNC Press Receives Grant from Mellon Foundation,' News \& Observer (Raleigh, NC), January 8, 2015, http://www.newsobserver.com/news/ local/education/article10216445.html.

27. For more information about Alt-Textbook, see https://www.lib.ncsu.edu/alttextbook.

28. T. Jared Robinson, Lane Fischer, David Wiley, and John Hilton III, 'The Impact of Open Textbooks on Secondary Science Learning Outcomes,' Educational Researcher 43, no. 7 (2014): 341-51; Lane Fischer, John Hilton III, T. Jared Robinson, and David A. Wiley, 'A Multi-institutional Study of the Impact of Open Textbook Adoption on the Learning Outcomes of Post-secondary Students, Journal of Computing in Higher Education 27, no. 3 (2015): 159-72.

29. I. Elaine Allen and Jeff Seaman, Opening the Textbook: Open Education Resources in U.S. Higher Education, 2015-16 (Babson Park, MA: Babson Survey Research Group, 2016), https://www.onlinelearningsurvey.com/reports/ openingthetextbook2016.pdf.

30. This estimate of bachelor degrees awarded to psychology majors comes from http://nces.ed.gov/programs/digest/d15/tables/dt15_322.10.asp?current=yes.

31. Allen and Seaman, Opening the Textbook.

32. Sutton and Chadwell, 'Open Textbooks at Oregon State University.' 